\title{
The Albanian Legal Framework on the Parents' Involvement in Schools
}

\author{
Ardian Tana \\ "Aleksandër Xhuvani" University, Elbasan, Albania \\ Email: ardiantana@yahoo.it
}

\section{Doi:10.5901/mjss.2014.v5n1p399}

\begin{abstract}
It is widely accepted that parents' involvement in the school plays a positive role in the students' results and their development. The concrete reality offers various perspectives. Whereever the school-family partnership is institutionalized and is considered to be important there is evidence of positive results, whereas there are many other cases in which this partnership does not function. The aim of this study is to analyze throughout the years, the Albanian legal framework regarding parents' involvement, its influence in fulfilling the school-family partnership and the teachers' evaluation of it.
\end{abstract}

Keywords: legal framework, parents' involvement, institutionalism, teachers' evaluation

\section{Introduction}

The parents' involvement in the school life is broadly accepted from various scholars as an important influencing factor in the quality of the school life and in the students' achievements. (Jeynes 2005; Hill \& Taylor 2004; Hill \& Tayson 2009; Avvisati, Besbas, \& Guyon, 2010). Schools and families are obliged to collaborate with one another, because they have a common objective: the child's education and development.

The reality shows that the school-family partnership does not always function properly. For this reason, many countries have sanctioned by law the parents' involvement in the school life, by defining the parents' rights, the organs and the associations through which the parents can exercise their rights. This way, the school-family partnership is not any more a free choice but it has been institutionalized, transforming it into an obligacion for the school and the teacher.

As Epstein states (2001), "We have moved from the question, Are families important for student succes in school? to, If families are important for children's development and school succes, how can help all families conduct the activities that will benefit their children?"

\section{The Albanian Context}

Albania, as an ex-communist country, does not have a rich tradition regarding the parents' involvement in the school life. The school-family communication was always a one-way communication from the school to the family, and this mainly happened when the school asked for this communication to occur, particularly in the cases of problematic students' behaviour. The extreme centralization of this relationship did not allow the creation of collaborative relationships between the school and the family, because the school was considered to be a very important institution, a servant to the ideology of that time.

The fall of communism created the opportunity for the "collapse of barriers" between school and family and all the continuous efforts on school democratization made those institutions more opened. On the other hand, the lack of tradition on this perspective has always been manifested as a strong obstacle for the construction of the school- family collaborative relations and the involvement of the parents in the school's life. This absence is shown in the teachers' and school staff's commitment to invite and accept the parents, but also in the parent's hesitation to do such a thing. The majority of parents in Albania were used to trust the function of their children's education to the school, considering themselves as not appropriate to deal with educational issues in the academic perspective as well as in the pedagogical one.

The main institutions, supported by a series of projects, have undertaken many initiatives to change this reality during the years. At first, there were made continuous interventions in the Albanian legislation to provide parents with their own rights to be involved in the school's life and on the other hand to oblige schools to get engaged in this process. There are also some good examples of collaboration between parent's associations and the local government and the 
Regional Education Department, though they were mostly related to individual commitments than institutional ones and they have not resulted to be long - termed (Elezi, 2010).

"Parents' involvement in Albania has reached a sensible institutional level through the presence of parents' councils and school boards" (Centre for Democratic Education, 2008).

However, the difficulties are always present in the implementation of the parents' involvement in the school practise. According to the findings of a study report within the parents' involvement project made by the Centre for Democratic Education and Open Society Foundation for Albania (2010), it is emphasised that there are some weaknesses in the parents' involvement. Among these weaknesses, we can mention the low level of the parents' awareness toward their role and the tendency to delegate the educator role to the school; teachers and school directors' deficient education regarding communication and collaboration with the parents etc.

On the other hand, even parents accept these difficulties. "The changes that were made have not eradicated yet from their minds (parents' - my note) that school educates the children, that all the school affairs are solved by a "strong" school director. This opinion is still alive because of the fact that the law is not enforced yet" (Elezi, 2010).

\section{The Legal Framework in Albania}

The parent's rights were firstly involved in the Normative Provisions of 1996 in Albania, derived by the Law $\mathrm{nr} .7952$, date 21.06.1995 "For the Pre- university Education System", where it is noted that "The collaboration between school institution and parents is a priority in the Albanian education". There are given some rights to the parents through this legal act:

The parents have the right to require to the school the provision of normal conditions for the teaching and education process, to get informed about the syllabus, objectives, regulations, to get regular information about their children's progress, about behaviours and school results, to be chosen and choose their representative in the school board, to participate in different school activities and extracurricular ones, to make complaints and written proposals to the school director's office, to the school's staff or to the board of directors and have the respective response within 30 days.

Parents have the right to be organized in school structures such as: class council or school council and parents' association as well, which are consultative structures. Parents' council of the class is composed of 3-5 members, whereas the parents' council of the school is composed of 5-15 parents. This types of councils have the right to express their own thoughts and advise about the progress or the improvement of the teaching and educative process.

The parents' council of the school collaborates with the school director's office regarding teaching process, provides the best collaboration possible with the pupils' families and community, local government, customers and donors. The council helps, advises and proposes an effective solution for the continuous school democratisation. Council representatives take part in the main analysis of the work of teachers' council.

Parents' association may be founded based on the free initiative of the parents in local or national level. Education authorities of all levels evaluate these unions as important partners, whose activity may be developed on basis of rights and functions determined in the actual status of these unions, which are approved in accordance with respective legal provisions.

School board functions as an essential, helpful and consultative body that helps in a more democratic administration of the main problems of the school and its management.

The creation of the school board is a matter of free initiative, conditions and real opportunities of school in the community where it acts.

The decision for the creation of a school board is taken by the school director along with the parents' council of the school and with the support of no less than $2 / 3$ of the members of teachers' council.

The board (when it is created) is composed of 5-7 parents of school pupils selected through a voting system by the parents' council, 2 representative of teachers' staff, 1-2 pupils, a customer or donor. The board chairman is selected through voting a representative of parents, whereas the school director, who is a member of the board, is its secretary in the same time.

The school board follows the main objectives of the school activity, annul programme of its activities, its needs and problems that concern school. It helps provide the normal conditions in school and with the implementation of its objectives.

After this legal act, it is approved the Normative Provisions in 2002, where there is again a special chapter about parents and their rights. 
The collaboration with the parents, like in the previous Provisions is qualified as an "advantage in the Albanian educational system". Parents' rights are almost the same, while there are some changes in the article 50 (Parents' Associations and the article 52 (School Board).

Differently from the previous document regarding parents' association, it is emphasised that 'educational authorities support and encourage the parents' association for the implementation and advocacy of their legal rights, creating favourable conditions for the utilisation of school environment in the view of their activity, material and financial support, the right to be informed and other facilities, without undermining their activity. Educational authorities do not intervene in their duties".

In this way, it is provided a support through these extensions to the unions for their functionality, different from the previous Provisions where associations are just parents' initiatives where school and authorities have no responsibility to ease their activity.

There are some changes in the article 52 as well. The creation of the school board isn't a matter of desire, but an obligation. "The board is an institution which represents the interests of the community where the school acts and operates as a decision-making body that contributes in a constructive way in the democratic management of the administrative and financial problems of the school and its administration". Again, the school director is a member and its secretary. The composition and other functions of him/her are still the same.

Being considered as a new structure in the educational system in Albania, it seems like the legal framework in relation with the school board has gone through some more frequent and bigger changes. Initially, it was considered as a structure that could be founded based on the schools' will and its creation was obligatory years later. Meanwhile, its management and functionality were mostly left to the school directing office, changing it in a very formal structure and without a meaningful influence in the school activity. Because of the misunderstandings regarding board's functionality and duties, in 2007, the Ministry of Education and Science issued a new manual "The creation and operation of school board". According to this Manual, the board is not created by the school director, but from the Regional Education Department and the headmaster is no longer a member, nor a secretary of this board.

Evaluating the major role of the parents' involvement in the school life, in the Law nr.69/2012, parents are considered as "crucial partners of the educational institution in the child's progress and of the educational institution as well".

This definition clearly shows the recognition of the irreplaceable role of parents, while in all previous legal acts the collaboration with parents is evaluated as a priority for the Albanian education.

In the Normative Provisions that accompany this Law, there are confirmed the same rights that parents used to have through previous documentations. Regarding school board, the school director is a member again and a secretary of this board in the same time.

What is still a concern in these terms, is the role of the school director "his impact is obtrusive for the board" (Elezi, 2010).

Important changes have been made in the decision- making process concerning the nomination of school director or teachers, empowering the parents' role in this way. There are school board chairman and the leader of parents' council in the valuation committee, which highly increases the role of the parents in the school life. There are added some executive powers to the board as well in the school budget administration, in collaboration with the director's office and local government, while schools have the right to have their own bank account for the incomes which derive from its activity for the third, sponsorships and other incomes that school has as well. The increase of decentralization level and board functions and the strengthening of parents' role are expected to give its impact on the progress of school life.

There are also changes in the internal and external evaluation process of the school, where one of the fields for the implementation of this process is the school- family collaboration in the Manual for the full inspection of school. The required standard is that "parents should be involved in school life and support children in the process of learning. Their views and ideas are evaluated and taken into consideration, school leaders create a stable relationship with the school board and there are some profits that are generated from the collaboration which are evaluated from all the actors".

The school- family consortium is institutionalised not only through legal acts that recognize school's duty and parents' right to be engaged in school life, but also through the determination of legal mechanisms regarding the control of the progress of school- family collaboration. But how does this consortium operate in reality? Do teachers and school leaders know the legal framework for the parents' involvement? How do they evaluate this legal framework? 


\section{Findings of a Questionnaire}

In order to obtain the evaluations of teachers and school staff regarding legal framework about the parents' involvement in school life, there was conducted a questionnaire with 300 teachers of pre-university schools, in cities and villages, in private and public schools.

$94 \%$ of teachers taught in public schools (281 teachers), whereas 6\% taught in private schools (19 teachers); 61.4 $\%$ belonged to cities' schools (181 teachers), whereas $38.6 \%$ to villages' school (38.6\%).

The tables show the answers of parents concerning the questions if they agree with the following statements:

The Law of Pre-university Education sanctions the parents' involvement in school affairs.

The parents' involvement should be regulated by the law or the minister's decree.

The parents' involvement is not appropriately regulated by law.

The legal framework must increase the parents' involvement in school and pupils' affairs.

The legal framework is unclear regarding parents' involvement in school affairs.

Table 1: The Law of Pre-university Education sanctions the parents' involvement in school affairs

\begin{tabular}{|l|c|c|}
\hline \multicolumn{1}{|c|}{ Answers } & Frequency & Percent \\
\hline Disagree & 22 & 7.3 \\
\hline Somehow agree & 38 & 12.7 \\
\hline I don't know/ uncertain & 145 & 48.3 \\
\hline Agree & 91 & 30.3 \\
\hline Totally agree & 4 & 1.3 \\
\hline
\end{tabular}

Table 2: The parents' involvement should be regulated by the law or the minister's decree

\begin{tabular}{|l|c|c|}
\hline \multicolumn{1}{|c|}{ Answers } & Frequency & Percent \\
\hline Disagree & 34 & 11.3 \\
\hline Somehow agree & 80 & 26.7 \\
\hline I don't know/ uncertain & 112 & 37.3 \\
\hline Agree & 71 & 23.7 \\
\hline Totally agree & 3 & 1.0 \\
\hline
\end{tabular}

The following question is a checking question regarding the received answers in the table 2 .

Table 3: The parents' involvement is not appropriately regulated by law

\begin{tabular}{|l|c|c|}
\hline \multicolumn{1}{|c|}{ Answers } & Frequency & Percent \\
\hline Disagree & 11 & 3.7 \\
\hline Somehow agree & 34 & 11.3 \\
\hline I don't know/ uncertain & 151 & 50.3 \\
\hline Agree & 101 & 33.7 \\
\hline Totally agree & 3 & 1.0 \\
\hline
\end{tabular}

Table 4: The legal framework must increase the parents' involvement in school and pupils' affairs

\begin{tabular}{|l|c|c|}
\hline \multicolumn{1}{|c|}{ Answers } & Frequency & Percent \\
\hline Disagree & 68 & 7.3 \\
\hline Somehow agree & 82 & 12.7 \\
\hline I don't know/ uncertain & 87 & 48.3 \\
\hline Agree & 63 & 30.3 \\
\hline Totally agree & 0 & 1.3 \\
\hline
\end{tabular}

Table 5: The legal framework is unclear regarding parents' involvement in school affairs

\begin{tabular}{|c|c|c|}
\hline Answer & Frequency & Percent \\
\hline \multicolumn{2}{c}{402} & \\
&
\end{tabular}




\begin{tabular}{|l|c|c|}
\hline disagree & 62 & 20.7 \\
\hline Somehow agree & 81 & 27.0 \\
\hline I don't know/ uncertain & 83 & 27.7 \\
\hline Agree & 70 & 23.3 \\
\hline Totally agree & 4 & 1.3 \\
\hline
\end{tabular}

\section{Discussions}

The fact that teachers really appreciate the parents' involvement in the school life is something that can be noticed immediately. They emphasize in their answers that this involvement must be regulated by law, or the legal framework must be clearer in respect of this involvement.

Meanwhile, it is evident that teachers don't know this legal framework and its purpose as largely as it is required. Almost in each case, those people who are uncertain reach the $50 \%$, while it is also added the percentage of those who agree or somehow agree to the same previous number.

Even though it is emphasised in the annual programme, that one of the first activities that is organized with teachers in the beginning of every school year is the legal framework and its update, it seems this is formally performed in the majority of school.

The law nr.69/2012 "About the pre-university educational system in the Republic of Albania" approved by the consensus of all political parties in Albania in 2012, clearly states the parents' involvement in the school life and evaluates their role as "crucial school partners", appointing more powers to them and for important decisions like headmaster's nomination or teachers' selection. In reality, it seems that this legal framework is not well recognised and transmitted.

It is weird the fact of headmaster's power retrieval concerning school board. The effort to give power to the parents in the decision-making process seems to be inappropriate in relation to this change. The fact that regular changes are associated with the school board shows that they have not been successful and not well studied and the parents' opinion seems to be missing as well.

\section{Recommendations}

It is necessary for schools to work more responsibly toward the recognition of the legal framework and especially the part related with parents, as it seems to be less known.

It might be very helpful in these terms if training agencies give their contribution; the recognition of the legal framework by the teachers must be included more in their training modules and this practice needs to be extended throughout the country.

Responsible inspective institutions and those that deal with external evaluation of schools have to strongly require not only the recognition but also the implementation of parents' rights and to respect their role in school life, as the determination of these rights in papers is one thing, and their implementation in the daily school life is another.

These changes made in the legal framework about the parents' involvement have not always been effective.

There must be some efforts regarding the strengthening of the parents' role in supporting their unions and providing conditions to their functionality, as well as the relation with the local government and Regional Education Department or Ministry of Education and Sports which should try and give more support from its part to the parents in order to consider them as partners in the Albanian education.

\section{References:}

Avvisati, F., Besbas, B. \& Guyon, N. (2010). Parental involvement in school: A literature review. Paris Scool of Economics. Available: htttp://www.parisschoolofeconomics.eu/docs/guyon-nina/parentalinvolvement pdf

Elezi, H. (2010). School board and decision- making, www.arsimi.al/qeverisja-e-shkolles

Epstein, J. L., (2001). School, family, and community partnerships. Preparing educators and improving schools, p. 42.

Hill, N. E. \& Taylor, L. C. (2004). Parental school involvement and children's academic achievement, pragmatics, and issues. Current Directions Psychological Science: A journal of the American Psychological Society, 13 (4), p. 161-164.

Hill, N. \& Tyson, D. (2009). Parental involvement in middle school: A meta-analytic assessment of the strategies that promote achievement. Developmental Psychology, 45 (3), p.740-763.

Jeynes, W. (2005). A meta-analysis of the relation of parental involvement to urban elementary school student academic achievement. Urban Education, 40, p. 237-269. 
Centre for Democratic Education (2008). Study report: The situation of parents' involvement in Albania

Centre for Democratic Education \& Open Society Foundation for Albania (2010).Parents' involvement in school life. Study report for Albania.

Law nr.7952, date 21.06.1995 "About Pre-university educational system".

Law nr.8387, date 30.07. 1998.

Law nr. 69/2012 about the pre- university educational system in the Republic of Albania, www.qbz.gov.al Normative Provisions about pre-university education, 1996.

Normative Provisions about pre-university education, 2002.

Normative Provisions about pre-university education, 2013.

Manual nr.40, date 17.10.2007 "The creation and operation of school board". 